\title{
THE PRESENT POSITION AND FUTURE PROSPECTS OF THE ELECTROLYTIC ALKALI AND BLEACH INDUSTRY.
}

By JOHN B. C. KERSHAW, F.I.C.

(A Paper read before the Faraday Society on Tuesday, February 19, 1907,

DR. T. M. LowRY in the Chair.)

\section{INTRODUCTION.}

Over fifty-five years have passed away since Charles Watt described in some detail how sodium or potassium hydrate and chlorine compounds could be produced by electrolysis of the corresponding chloride in a diaphragm cell, and nearly twenty years have passed since a process worked upon this principle was developed industrially at Griesheim in Germany. The claim made that Watt's patent, No. 13,755 of $185 \mathrm{I}$, should be recognised as the master-patent of the electrochemical and electrometallurgical industries is substantiated, the more one studies it. The author has lately been instrumental in having this remarkable patent reprinted by H.M. Patent Office, and all interested in the historical side of the development of these new industries can now obtain and study it for themselves.

It is unnecessary to explain to this audience why Watt's ideas lay dormant for thirty-five years, or why it was only towards the end of the eighties that electricians and chemists commenced to experiment upon an industrial scale with cells designed for the electrolytic production of alkali and chlorine from sodium or potassium chloride. The earliest attempts appear to have been made in Germany. According to Lunge,* in $188_{4}$ three German firms contributed to a common fund for carrying out experiments upon the electrolysis of the alkali chlorides. It may be remarked here that this method of obtaining funds for industrial research work is widely employed in Germany, and judging by the results attained it has much to recommend it. As fruit of these experiments, which were continued for four years, the "Elektron" diaphragm type of cell was evolved, and a small experimental plant was erected at Griesheim, near Frankfort, in 1889 , to test it upon a larger scale. This plant commenced work with 200 H.P. in the following year. In 1892 this plant was doubled in size and was visited by Lunge, who convinced himself that it was working economically. A larger plant using the same cell and process was erected at Bitterfeld, in Saxony, in 1893; this commenced work in 1894 , and was doubled in size in 1895 . It is not the author's purpose in this paper to trace the later developments of the "Elektron" cell and process. It will suffice to say that it is now adopted in the majority of the European works, and that as far as one can judge from the financial returns, it works satisfactorily and economically. Potassium chloride is the salt electrolysed in several of these works on account of the higher yield and more valuable end products. The diaphragms used in the cells are stated by Haber to be made of cement. With great care it is said they can be made to last two years, but the correctness of this statement may be doubted.

Turning now to the history of the English processes, we find that the earliest industrial trials were made with Greenwood's asbestos diaphragm

- Zeits.f. angere. Chemie, r896, p. 517 . 
cell at Snodland, in Kent, in $189 \mathrm{I}-92$. These were unsuccessful, and were followed by the trials at the same place of the Richardson and Holland bell type of cell patented in 1890 . The trials of this cell at Snodland led to the promotion of the Electrochemical Company with a capital of $f_{150,000}$ and to the erection in $1894-95$ of a large works at St. Helens, in Lancashire. These works were started in December, 1895, with plant utilising I, I00 H.P. After a chequered career these works were finally closed down in I900. The Castner cell was patented in 1892 and 1893 . After trials at Oldbury the cell was exploited upon a large scale at the Castner Kellner Works, near Runcorn, erected in 1895-96, and started in 1897 . The Middlewich Works of the Electrolytic Alkali Company followed in 1899-1900, a very long period of trial having been allowed to elapse between the patenting of the Hargreaves-Bird type of cell in I892-93 and its industrial development upon a large scale. The early experiments with this cell were carried out at Farnworth, near Widnes.

As regards America, the earliest electrolytic alkali works was erected at Rumford Falls in 1892. The Le Sueur diaphragm cell was employed here, and three tons of bleach were produced per day. The Mathieson Works at Niagara Falls, using Castner's cell, was not erected until 1897-98, and started in the latter year with 2,000 H.P. This works has since been taken over by the Castner Electrolytic Company, and has been greatly enlarged.

These historical details show clearly that, although Charles Watt was the originator of the idea underlying the electrolytic alkali processes, German engineers and chemists by steady and long-continued industrial research work, were the first to develop it. German capitalists and engineers have also reaped some advantage from this early work, for the larger number of the electrolytic alkali works on the Continent of Europe are now using the "Elektron" cell, and are under the technical control of the Griesheim firm. Though the financial results of the developments have in many cases been disappointing, the orders for plant and machinery placed in Germany, and the demand for chemists and managers to take charge of these subsidiary works, likewise drawn from the Fatherland, will, no doubt, have been regarded as satisfactory compensation for the small dividend-earning capacity of certain of these undertakings, especially when floated, as many were, with the aid of foreign capital.

In the following pages it is not the author's intention to give a detailed description of each cell and process now in actual use for the production of alkalies and chlorine compounds by the electrolysis of chlorides. The majority of the members of this Society are already well acquainted with these details, or know exactly where to find them when required. What the author proposes to give is a list of works now operating in Europe and America, with a brief summary of the facts relating to the power used, type of cell and process employed, and products made.

This information is based as far as possible upon the replies to a circular letter sent out to all the companies operating these processes in the spring of 1906. The replies to this letter were, however, disappointing, since in a very large number of instances a letter stating that no information could be given was received. It has therefore been necessary to supplement the official information by facts and figures drawn from reliable technical journals and from other sources, and from private reports sent to the author by correspondents in France and other countries. Only those who have attempted to obtain information as to the progress of the electrochemical industries will realise the excessive modesty of electrochemical firms about their achievements, or the objection there is on the part of manufacturers to allow the 
world to know what is being done and what progress is being made. Whether this reticence is a sign of prosperity or the reverse, the writer will not attempt to decide.

\section{DETAILS OF PROCESSES AND WORKS.}

\section{UNITED KINGDOM.}

I. The Castner Kellner Alkali Company.

Established 1898. New works opened 1906. Works: Weston Point, Cheshire; Wallsend, Newcastle.

Process.-Castner mercury process with Kellner's modification.

Products.-Caustic soda, bleaching powder, sodium, sodium peroxide, zinc chloride.

Power.-Weston Point, 5,000 to 7,000 H.P., Mond gas-producer plant and gas engines. Wallsend, 2,000 H.P., to be purchased from Supply Company.

2. The Electrolytic Alkali Company.

Established rgor. Works : Middlewich, Cheshire.

Process.-Hargreaves-Bird diaphragm.

Products.-Carbonate of soda, bleaching powder, salt, caustic lime.

Power.-3,000 H.P., steam.

The Electrochemical Company, which worked the Richardson and Holland bell cell at St. Helens from 1895 to I90o, failed to attain financial success, and liquidated its assets in roor.

Messrs. Brunner, Mond \& Co. manufacture bleach by the Hoepfner process at Winnington, in Cheshire, but this works can hardly be classed as an electrolytic alkali and bleach works.

\section{France.}

\section{Société Industrielle des Produits Chimiques.}

Established I900. Works at La Motte-Breuil.

Process.- "Elektron."

Products.-Caustic soda and bleaching powder.

Power.-2,000 H.P., steam.

The following works have ceased the manufacture of alkali and blcach by the electrolytic method in France during the last few years :-

\begin{tabular}{|c|c|c|c|c|}
\hline Société des Soudiere & jue & & & Les Clavaux. \\
\hline Société la Volta Lyonnaise ... & ... & & $\ldots$ & Montiers. \\
\hline Société des Fives-Lille $\quad \ldots$ & ... & •. & $\cdots$ & Bozel. \\
\hline Société des Produits Chimiques & $\ldots$ & •. & $\ldots$ & Monthey. \\
\hline
\end{tabular}

In some of these works subsidiary electrolytic manufactures, such as the production of sodium and sodium peroxide, are now being carried on, and, no doubt, if the financial position in the alkali industry improved, some portion of the power available would again be devoted to the production of alkali and bleach.

\section{SWITZERLAND.}

4. Société la Volta Suisse de l'Industrie Electrochimique.

Works : Chevrés, near Geneva.

Process.-Outhenin Chalandre diaphragm.

Products.-Caustic soda and bleaching powder.

Power.-I,000 H.P., water. 


\section{GERMANY.}

5 and 6. Chemische Fabrik Griesheim "Elektron."

Established 1890 . Works at Griesheim, near Frankfort, and at Bitterfeld.

Process.-" Elektron."

Products.-Caustic potash, caustic soda, potassium, sodium, magnesium, and bleaching powder.

Power.-Griesheim, 400 H.P., steam. Bitterfeld, 3,600 H.P., steam.

7 and 8. Elektrochemische Werke. G.m.b.H.

Established I894. Works at Bitterfeld and at Rheinfelden.

Process.- "Elektron."

Products.-Alkalies and bleach, sodium, magnesium.

Power.-Bitterfeld, 3,500 H.P., steam. Rheinfelden, 2,800 H.P., water.

These last two works have recently been taken over by the Chemische Fabrik Griesheim "Elektron," and the four works are now under the one management and control.

9. Badische Anilin und Soda Fabrik.

Process.-" Elektron."

Works : Ludwigshafen.

Products.-Caustic soda and potash and chlorine compounds.

Power.-3,300 H.P., steam.

ro. Consolidierte Alkali Works.

Process.-" Elektron."

Works : Westeregeln.

Products.-Caustic potash and bleaching powder.

Power.- r,300 H.P., steam.

II. Deutsche Solvay Company.

Established $1896 . \quad$ Works : Osternienberg.

Process.-Solvay mercury process.

Products.-Caustic potash and bleaching powder.

Power.-I,500 H.P., steam.

AUstria.

12. Oest. Verein f. Chemische Production.

Established 1899 . Works : Aussig.

Process.-Bell gravity process.

Products.-Caustic soda and bleaching powder.

Power.-2,000 H.P., steam.

13 and 14 . Consortium $f$. Elektrochem. Industrien.

Established rgoo. Works : Golling and Jaice in Bosnia.

Process.-Kellner mercury process.

Products.-Alkali and chlorine compounds.

Power.-Golling, 200 H.P.; Jaice, I,000 H.P.; water.

The author is informed by his correspondent in Austria that the projected enlargement of the experimental works at Golling has not been carried out.

15. Lubinoff Solvay \& Cie.

Russia.

Established I gor. Works : Donetz.

Process.-Solvay mercury.

Products.-Caustic soda and bleaching powder.

Power.-1,500 H.P., steam. 
16. Zabkoreickie Zaklady Elektrochemiczne. T. A. Elektrycznon.

Established I899. Works: Zabkowickie.

Process.-

Products.-Caustic soda and bleaching powder.

Power.-I,200 H.P., steam.

17. Gesellschaft Russki "Elektron."

Established I900. Works: Slaviansk.

Process.-"Elektron."

Products.-Caustic soda and bleaching powder.

Power.- $x, 000$ H.P., steam.

In view of the disturbed state of Russian finance and industry, it may be doubted whether these three works are now operating, and in the tabular statement at the end of this section they have been classed as "suspended."

ITALY.

18. Societa Elettrica ed Elettrochimica del Caffaro.

Established Igo6. Works: Caffaro Falls.

Process.-

Products.-Caustic soda and bleaching powder.

I9 and 20. Societa Elettrochimica Italiana.

Works: Piano d'orte and Bussi.

Process.-Outhenin-Chalandre.

Products.-Alkalies and bleaching powder, chlorates, carbon tetrachloride, pure hydrochloric acid.

Power.-6,000 H.P., water.

Elter, in a recent report, states that the financial results obtained in these two works have been disappointing, owing to their unfavourable position and to the high price of salt.

\section{SPAIN.}

21. Sociedad Electro-Quimica de Flix.

Established 1900. Works: Flix on the Ebro.

Process.-“Elektron."

Products.-Caustic soda, bleaching powder, and hypochlorite.

Power.-3,000 H.P., water.

22. Sociedad Anon. Electra del Besaya.

Established rgor. Works: Santander.

Process.-Outhenin-Chalandre.

Products.-Caustic soda and bleaching powder.

Power. -700 H.P.

23. L'Usine d'Abonos.

Gas power.

Works : Gijon.

At present stopped.

\section{Belgium.}

24. Solvay \& Cie.

Established $\mathrm{r} 898$. Works : Jemeppe-sur-Sambre.

Process.-Solvay mercury process.

Products.-Caustic soda and bleaching powder

Power.-1,500 H.P., steam: 


\section{United States.}

25. Castner Electrolytic Alkali Company.

Established 1898. Works: Niagara Falls.

Process.-Castner Kellner mercury.

Products.-Caustic soda and bleaching powder.

Power.-6,000 H.P., water.

26. The Pennsylvania Salt Company.

Established . Works: Wyandotte, Michigan.

Process.-Bell Brothers' mercury.

Products. - Caustic soda and bleaching powder.

Power.- H.P., gas.

27. The Roberts Chemical Company.

Established . Works: Niagara Falls.

Process.-Roberts' diaphragm.

Products.-Caustic potash, pure hydrochloric acid.

Power.-500 H.P., water.

This works is reported to have been burnt down recently.

28. The Acker Process Company.

Established 1899, Works: Niagara Falls.

Process.-Acker fusion with lead cathode.

Products.-Caustic soda, bleaching powder, carbon tretrachloride and tin tetrachloride, sulphur bichloride.

Power.-2,000 H.P., water.

29. The Burgess Sulphite Wood Pulp Company.

Established x9oo. Works: Berlin Falls.

Process.-Le Sueur diaphragm.

Products.-Bleaching liquors only.

Power. -700 H.P., water.

30. The Dow Process Company.

Established . Works: Midland, Michigan.

Process.-Dow diaphragm.

Products.-Bleaching liquors, bromine.

Power.- H.P., steam.

\section{Canada.}

31. The American Alkali Company.

Established 1901. Works: Sault Sainte Marie.

Process.-Rhodin.

Products.-Caustic soda and bleaching powder.

Power.-2,000 H.P., water.

This works only operated from January, I901, to September, I902, and is now shut down.

A new works, using the Townsend diaphragm cell, is about to be started at Niagara Falls.

There are, in addition, in America a considerable number of small electrolytic alkali installations worked in connection with wood-pulp mills. These employ, as a rule, a diaphragm cell process, and use the caustic soda liquors and chlorine directly in the pulp mill. The installation of the MacDonald cell at the Clarion Paper Mills, Johnsonburg, Pa., is of this type. The same cell and process are being employed at Colorado City, for providing a solution to open up gold-bearing ores. These plants, however, cannot be correctly classed as electrolytic alkali works. 
Summarising the details given in this section of the paper, we obtain the following totals :-

\begin{tabular}{|c|c|c|c|c|c|c|}
\hline \multirow{2}{*}{ Country. } & \multicolumn{4}{|c|}{ Works. } & \multicolumn{2}{|c|}{ Horse Power.* } \\
\hline & Operating. & Closed. & Suspended & Building & Employed. & Extension \\
\hline United Kingdom... & 2 & I & 0 & $\mathbf{I}$ & 9,000 & 2,000 \\
\hline $\begin{array}{lll}\text { France } & \ldots & \ldots\end{array}$ & I & o & 4 & o & 2,000 & 6,000 \\
\hline Switzerland & I & o & o & o & $\mathrm{I}, \infty 00$ & - \\
\hline Germany ... & 7 & o & o & o & $\mathbf{1 6 , 0 0 0}$ & - \\
\hline Austria $\quad \ldots$ & 3 & o & 0 & o & 3,200 & 一 \\
\hline Russia $\quad \ldots$ & o & o & 3 & o & - & 3,700 \\
\hline Italy $\quad \ldots$ & 3 & 0 & o & o & $6, \infty 00$ & - \\
\hline Spain $\quad \ldots$ & 2 & 0 & I & o & 3,700 & 1,000 \\
\hline Belgium $\ldots . \quad \ldots$ & $\mathbf{I}$ & o & 0 & 0 & $\mathrm{I}, 500$ & - \\
\hline United States and & & & & & & \\
\hline Canada ... $\quad \ldots$ & 7 & I & 0 & 0 & II 700 & - \\
\hline Totals... & 27 & 2 & 8 & $\mathbf{I}$ & 54,700 & 12,700 \\
\hline
\end{tabular}

The totals show that about 55,000 H.P. are now being devoted to the production of alkalies and bleach by the electrolytic method, and that plant representing about 13,000 H.P. is lying in reserve, ready to be put into operation when the local conditions improve.

Assuming that all the plants are being worked to the best advantage, the production of 70 per cent. caustic soda at present would be about i ro,000 tons per annum, with an equivalent of $23 \mathrm{I}, 000$ tons of 35 per cent. bleaching powder ( 2 tons of caustic and $4^{*} 2$ tons of bleach per E.H.P. year).

There are no figures available for showing how these totals compare with the production of alkalies and bleach by the old Le Blanc Works, but it is of interest to note that the exports of bleaching powder by this country since I 900 have averaged about 50,000 tons per annum. In the year 1896 , which is the last year for which the figures are available, 360,000 tons of salt were decomposed by the Le Blanc Works in the United Kingdom. At the rate of 36 cwts. of salt per ton of bleach this would be equivalent to a production of 200,000 tons of bleaching powder.

\section{THE FUTURE OF THE ELECTROLYTIC INDUSTRY.}

Prophecy in these modern days, when so many influences are at work to disturb the general lines of progress, is more uncertain and hazardous than in the days of our ancestors. It would be a mistake, however, to close this paper without some attempt to forecast the future development of the electrolytic alkali industry, and to indicate the lines upon which its further progress is likely to occur. The figures given at the close of the second section of this paper prove that the development of the industry since rooo has undergone a check, for Professor Borchers, in a paper published in the Zeits. f. Elektrochemie, of July 20, 1899, gave a list of works engaged in this industry, and estimated the aggregate production of bleaching powder in that year at 225,000 tons. Further evidence of this check is found in the reports received by the writer of the present position of the industry in

* These figures must be regarded as estimates only, and as not of official value. 
France and Spain, from correspondents who are well acquainted with the facts. In France the industry is stated to have had a set-back during the last five years, an experience partly due to the defects of the processes themselves, and partly due to the competition from the old Le Blanc Works. These have sold bleaching powder at so low a price that its sale has not yielded any profit to the electrolytic works, and the competition has thus discouraged the financial development of newer and more efficient electrolytic processes. In Spain it is stated that the prospects of the industry at present are not bright. The Le Blanc Works in Europe are, in fact, making a better fight than was expected ten years ago, and it would seem probable that they will continue to exist side by side with the electrolytic works for many years to come. It is interesting to note that when the Ammonia Soda process was introduced into this country, the early decease of the older Le Blanc process was likewise confidently predicted. Threatened industries, however, like ailing people, have sometimes a long life. In the writer's opinion all three types of works, Le Blanc, Electrolytic, and Ammonia Soda, will find a place in the chemical industry of the future.

The character of the chief manufactured products in each type of works may change, but the works themselves will survive. Some indications of this change already may be observed, for bleaching powder and caustic or carbonate of soda are no longer providing large profits for their producers by the Le Blanc or electrolytic processes, and it is the by-products and special manufactures of each type of works that are now providing the dividends.

The following tabular statement, giving the average price of bleaching powder and $5^{\mathbf{8}}$ per cent. soda ash in December of each year for the period

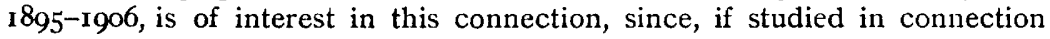
with the balance-sheets of the various companies, it serves to indicate the source of the profits of the three processes used in the manufacture of alkali and bleach :-

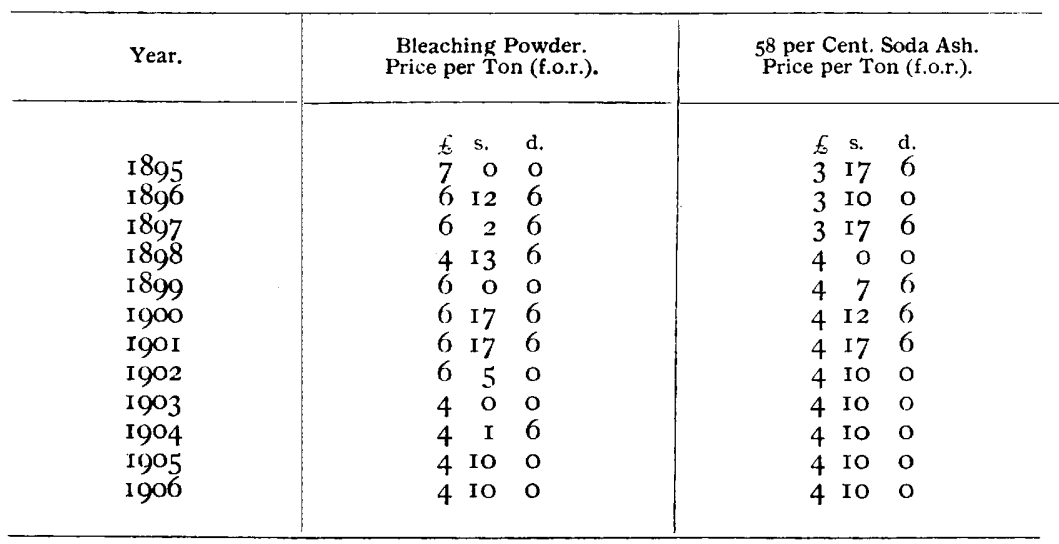

(Prices compiled by The Chemical Trade Fournal.)

The writer's conclusions regarding the future of the alkali and bleach industry generally may be summarised as follows :-

The Le Blanc Works will continue to produce caustic and carbonated alkali and bleaching powder, but in diminishing quantities, and the dividends earned by manufacture of these staple products (which once yielded large profits) will decline. But compensation for this loss will be found in the 
manufacture of sulphuric acid, sodium sulphate, hyposulphite, sulphide, and other derivatives from these sulphur salts which cannot be manufactured by the processes of either of their rivals, and even the impurities of the pyrites burnt in the kilns for the lead chamber process of sulphuric acid manufacture may be looked upon as an important source of revenue in years to come. Copper sulphate is another by-product, yielding its makers handsome profits, which can be most successfully made by the Le Blanc manufacturers. The Le Blanc Alkali Works will then depend more and more upon by-products, and less and less upon the staple products, soda and bleach, for their future profits. With this change will come the need for increased foresight and scientific supervision in their management and control.

The Electrolytic Works, when operating a good process, and when under wise financial management, will gradually take the place of the Le Blanc Works as producers of bleaching powder, chlorates, and other chlorine products. The manufacture of metallic sodium and its derivatives, such as cyanides and peroxides, will also fall into the hands of the electrolytic manufacturers. The cost of operating the electrolytic process of alkali manufacture is, however, greater than was at first estimated, and only the best processes and best equipped works will survive in the struggle for existence.

The Ammonia Soda Works, both in this country and abroad, will continue to make enormous profits out of the manufacture of carbonate and bicarbonate of soda by the Solway process. But what is regarded by many as the best feature of these works, namely, the absence of by-products, is, judged from another standpoint, a source of weakness.

The Ammonia Soda Works can never entirely take the place of the Le Blanc or Electrolytic Works, since neither sulphur nor chlorine products can be made a subsidiary and successful part of the manufacture of soda by the Solvay process. All attempts hitherto made to extract chlorine successfully from the waste calcium chloride liquors of these works have failed, and the Hoepfner process of zinc extraction, which has been in operation at Winnington for some years, cannot be considered to meet the demand for a satisfactory and profitable use for these waste liquors of the Solvay process. If such a process be ever found and successfully developed, the forecasts given in this article will require revision, and their author may have to accept the fate of many another prophet and to confess that in this world "nothing is certain but the unforeseen."

\section{APPENDIX.}

I. Castner Kellner.

\section{Mercury Type of Cells.}

The Electrical Review (London), March 3I, I899.

2. Solvay.

Zeits. f. Elektrochemie, September 8, 1905.

Electrochemical Industry, November, 1905.

\section{Diaphragm Type of Cell.}

I. Hargreaves-Bird.

The Electrician, February I2, I897, and February I8, I898.

The Electrician, March I4, I902.

2. Outhenin-Chalandre.

Electricity (New York), April I7, I901.

3. Townsend.

Electrochemical Industry, May, 1905.

4 Zerr and Whitham.

Electrochemical Industry, January, 1906. 
Fusion Type of Cell.

r. Hulin.

Electrician, March 4, I898.

2. Acker.

Electrician, October 25, I90I.

Gravity Type of Cell.

I. Aussig "bell" cell.

Electrician, February 7, 1902.

Zeits. f. Elektrochemie, October ro, Igor.

Electrochemical Industry, June, 1904.

Siebert.

General Articles.

Elektrochemische Zeitschrift, November, 190I

Franke.

American Electrician, March, I90I. 